\title{
MULTIRESISTANT MICROORGANISM INFECTION IN NEWBORNS AT AN INTERMEDIATE NEONATAL CARE UNIT AND INTENSIVE CARE UNIT OF REFERENCE: CROSS-SECTIONAL STUDY
}

\author{
INFECÇÃO POR MICROORGANISMO MULTIRRESISTENTE EM RECÉM- \\ NASCIDOS NA UNIDADE DE CUIDADOS INTERMEDIÁRIOS NEONATAIS E \\ UNIDADE DE CUIDADOS INTENSIVOS DE REFERENCIA: ESTUDO \\ TRANSVERSAL
}

\begin{abstract}
Flávio Henrique Alves de LIMA ${ }^{1}$; Cácia Régia de PAULA ${ }^{2}$; Jade Alves de Souza PACHECO³ Bruno Bordin PELAZZA ${ }^{4}$; Guilherme Silva de MENDONÇA ${ }^{5}$; Maria Alves BARBOSA ${ }^{6}$; Marinésia Aparecida da SILVA ${ }^{7}$

1. Federal University of Goiás, Faculty of Medicine, Jataí, Goiás, Brazil; 2. Federal University of Jataí, Goiás, Brazil; 3. Federal University of Goiás, Faculty of Medicine, Jataí, Goiás, Brazil; 4. Institution University of the Midwest, Department at the State University of the Midwest; 5. Institution Federal University of Uberlândia, Uberlândia, Hospital de Clínicas de Uberlândia, Uberlânida, MG, Brasil;6. Federal University of Goiás, Faculty of Medicine, Jataí, Goiás, Brazil;7. University of São Paulo, São Paulo, Brazil
\end{abstract}

\begin{abstract}
The objective was to describe the infection profile of multidrug-resistant organisms of newborns (NB), admitted to the neonatal intermediate care unit and the intensive care unit. It was a descriptive cross-sectional study of epidemiological nature, composed of 931 medical records and/or Hospital Infection Control Committee notification records, during the period of June to September 2012. Eight hundred and seventy newborns (NB) were admitted to the neonatal intensive care units and to intermediate care, with a final sample of $45 \mathrm{NB}$ presenting bloodstream infections (BSI) caused by multiresistant microorganisms. From the analyses, the following results were highlighted: gestational age $<37$ weeks in $42(93.3 \%)$; low weight at birth between $<750 \mathrm{~g}$ to $1.499 \mathrm{~g}$. The profile for resistance to enterobacteriaceae was $100 \%$ for cefepime and ceftazidime concerning non-fermenting gram-negative bacteria, it was found that (100\%) of P.aeruginosa was resistant to aztreonam, (100\%) of S. maltophilia resistant to ceftazidime and to gentamycin, however, $(1.1 \%)$ of S. aureus isolates were resistant to oxacillin and (12.5\%) of S. haemolyticus demonstrated a confirmed resistance to vancomycin. These results are worrying and express the importance of correct monitoring, and the need for producing a propaedeutic protocol in consensus with the multiprofessional team through the Hospital Infection Control Committee and managers, which is then implemented and regularly assessed by the service.
\end{abstract}

KEYWORDS: Microbial resistance to medication. Resistance to multiple medications. Patient safety. Child health services. Newborn.

\section{INTRODUCTION}

The movement toward quality care and safety of the patient in health services has been the most important proposal from the World Health Organization (WHO) for the new millennium (BELELA-ANACLETO et al., 2013; CAVALCANTE; PADOVEZE, 2012).

In this scenario, the use of new technologies in health, together with the practice of care, therapy, contamination by the microbiota of the environment and the immunocompromising of newborns (NB) in intermediate care units (IMCU) and neonatal intensive care units (NICU). These factors go on to favor cross-contamination and consequently the development of infections, including health-careassociated infections (HCAIs), which are considered an adverse event (AE) of great impact on the health of the newborn (TOMAS et al., 2015; SILVA et al., 2016).

In the context of neonatal intensive care, HCAIs have been the motive for concern for students studying this theme. Such concerns are founded, among others, on the fact that these microorganisms are notoriously involved in aggravating episodes, and thus become resistant to the antibiotics (ATB), included among these are Staphylococcus aureus, Staphylococcus Coagulase negative staphylococci (CNS), Enterococcus spp., Escherichia Coli, Klebsiela spp. and Enterobacter spp., Pseudo monasaeruginosa, Serratiamarcencens, Acinetobacter spp., Stenotrophomonas maltophilia and Candida ssp (SILVA et al., 2016; DE SÁ et al., 2019; MEDEIROS et al., 2015). 
It is important to emphasize here that these microorganisms have evolved a complexity of mechanisms with respect to the phenomenon of resistance. In this scenario, the hospital environment becomes a constant threat, thus constituting a chronic problem in public health (TOMAS et al., 2015; MEDEIROS et al., 2015; HAWKEY, 2015; GARLAND et al., 2017).

The rates of hospital-acquired infection concerning NB vary between 8.4 and $26 \%$ in developed countries, while in the NICU in Brazil these can vary from 18.9 to $57.7 \%$ (DE SÁ et al., 2019). Such infections affect up to $30 \%$ of newborns and with rates that can reach rates five times higher in this population, when compared to older children.

These findings have awoken the interest of professionals and researchers on the theme, including investigations on prevention and control methods of infection in the IMCU and NICU, especially when referring to new technologies in health, acquisition and safe use of ATB (SILVA et al., 2016).

In corroboration with this understanding and the complexity that surrounds the context of infections, in a distinct manner, those that dig deeper into the healthcare of the NB stress the difficulties concerning the adoption by professionals of recommended safety measures, that is, the professional team is involved in the epidemiological chain of the infection, by direct or indirect means (ESCOSTEGUY; PEREIRA; MEDRONHO, 2017; BARBOSA, 2019).

Cross-sectional studies help identify the prevalence of microorganism occurrence and its relationship with the variables, as well as aid the investigation into risk and protection factors and as such reduce the risk of infection (PAULA et al., 2018; CARVALHO et al., 2016), thus, this study aimed to describe the profile of infection by multidrug-resistant NB organisms, admitted to the neonatal intermediate care unit and the intensive care unit

\section{METHOD}

Descriptive cross-sectional study of epidemiological nature, developed at a state Institution Specialized in Maternal and Infant Health, integrated with the Public Health System (SHP) in a capital of the Central-West of Brazil.

The study scenario was a medium to high complexity hospital, inaugurated in 1972, which has an importance established for the region, through its reference for Brazilian states for gynecology and obstetrics (climacteric, sterility, general gynecology, general oncology, mastology, family planning, highrisk prenatal care, etc.) and pediatrics (children from 0 to 16 years old), also providing an Emergency service in pediatric and obstetrics with 24-hour care. The hospital has a partnership with various Health Care Programs as for example, Services to Victims of Sexual Violence; Palatal Lip Cleft Rehabilitation Center; Growth and Development; High Risk Speech-Language Pathology; Children's Hospital; Family planning; Scientific research; Prenatal of High Risk; Kangaroo Project; Project Gestate. There is also the commitment toward creating a teachinglearning environment for undergraduate, graduate and technical courses in the area of health of the state of Goiás and Tocantins. This is a unit has 164 registered beds, distributed over several specialties, according to National Registry of Health Establishments and has a multidisciplinary team composed of 860 professionals from different categories (DATASUS, 2019).

Data collection was performed during the period of June to September 2012, developed through the manual analysis of antibiotic use control records, which were available in the files of the hospital infection control commission (HICC) and the medical records for NBs and their respective mothers (in cases of missing information on the medical records of the NB). The retrospective collection of data referred to admissions of NBs in the IMCU and NICU over the period from March of 2011 to March 2012.

There was no sample size calculation performed, as the intention was to work with the total number of medical records for the NBs admitted in the period established for this research study. The following inclusion criteria were adopted for the study: a) HICC files and/or medical records of NBs admitted to the IMCU and NICU during the period of March 2011 to March 2012; b) HICC files and/or medical records of the NBs admitted to the IMCU and NICU that show use of antibiotics and a blood culture with a positive result and growth of multiresistant microorganisms (MMR). Excluded from the study were files and/or medical records of NBs admitted to the IMCU and NICU that besides having used antibiotics did not register a positive blood culture or for which growth was of other colonies, such as fungus, as well as NBs that were admitted to other sectors of the hospital.

In the present study, the variables investigated were sex, age, gestational age, prenatal, Apgar, birth weight, previous maternal infection, admittance period, type of delivery and discharge (deaths/transferences), result of positive blood 
culture exam, established antimicrobial therapy and isolated microorganism.

The data were tabulated on the worksheet of the Excel $^{R}$ program and posteriorly use was made of the software Statistical Package for Social Sciences (SPSS) version 17 for Windows, through the simple descriptive statistical method. In the discussion of the study, files available on the internet were used, where the following research terms were used Microbial Resistance, Patient Safety and Pediatrics.

This study is part of a larger Project entitled: Predictors for colonization/contamination of professionals, users, articles and surfaces of a Maternal and Child Health Institution integrated to SUS, with the favorable opinion from the Research Ethics Committee of the Federal University of Goiás, under the protocol $\mathrm{N}^{\mathrm{o}} 03 / 2012$, according to Resolution CNS $n^{\circ} 466 / 12$, with the consent of this committee for the exemption of the signature of the free and clarified consent term (FCCT), as it is a research study using secondary data.

\section{RESULTS}

The analysis was initiated with 931 medical records and/or files, from these 61 were excluded as they were not from NBs admitted to the IMCU and NICU. The remaining 870 medical records and/or files were submitted to a meticulous manual analysis, of these 766 used empirical antimicrobial treatment (antibiotics), but had no record of blood culture request and in 104 used antibiotic and contained this record. Among the 104 medical records and/or files, 35 possessed blood culture results without microorganism growth and 69 possessed positive blood culture results with microorganism growth. From these 69 files and/or medical records, in 19 fungal growth was registered and for this reason were excluded for not meeting the inclusion criteria defined by the research study, and 5 medical records and/or files were duplicated, thus resulting in a total of 45 medical records and/or files eligible for the research study.
The sample of newborns admitted to the IMCU and NICU of the study institution, with infection by multiresistant microorganisms, demonstrated that there was a predominance of admittances in the NICU $(62.3 \%)$, male gender (64.4\%), year of birth 2011 (57.8\%), gestational age $<37$ weeks (93.3\%), birth weight of 1000 to 1499 $\mathrm{Kg}(35.5 \%)$, normal birth $(53.3 \%)$ and mortality at $17.8 \%$.

Considering the prognostic importance of the Apgar, in the first minute a minimum of 0 and maximum of 9 was verified, with an average of 5.2. While the Apgar presented in the fifth minute, varies from 5 to 9 with an average of 7.5.

Upon analyzing the files and/or medical records of NBs, it was noted that these were incomplete, thus making it necessary to search for data on medical records of the mothers for Investigation of Bloodstream Infection (IBSI) (COSTA et al., 2016). Regarding the prenatal follow-up of pregnant women of the 45 (100\%) NB, $35(78.0 \%)$ had follow ups with an average of 5.34 appointments per expectant mother, where 22 $(48.8 \%)$ of these presented prior events that contributed to infection of the NB. There also occurred, rupture associated with urinary tract infection in $(2.2 \%)$, untreated syphilis in $(2.2 \%)$ and two $(4.4 \%)$ with vaginosis at the time of delivery.

Noted also was that, $35(77.7 \%)$ NB were submitted to some type of Central Venous Catheter (CVC) during admission, of these, 22 (48.8\%) used Peripherally Inserted Central Venous (PICC), 4 $(8.8 \%)$ Umbilical catheter (UC) and 9 (20.0\%) Single lumen catheter (SLC).

Another important indicator, for diagnosing infection in this population, are results from the blood culture exams of the NBs. The analysis of these results made it possible to delineate the following resistance profile of microorganisms to ATB, used in the therapy given to NBs admitted to the research units. Tables 1 and 2 .

Table 1. Antimicrobial resistance profile of Enterobacteriaceae isolated from the blood culture exams of NB $(\mathrm{N}=45)$ admitted to the IMCU and NICU, at an institution specialized in maternal-infant health.

\begin{tabular}{|c|c|c|c|c|}
\hline ANTIMICROBIALS & $\begin{array}{l}\text { Echerichia } \\
\text { coli }(\mathrm{n}=02)\end{array}$ & $\begin{array}{c}\text { K. oxytoca } \\
(\mathrm{n}=01)\end{array}$ & $\begin{array}{c}\text { K. pneumoniae } \\
(\mathrm{n}=01)\end{array}$ & S. marcescens $(\mathrm{n}=01)$ \\
\hline Amikacin & $50 \%$ & 0 & 0 & 0 \\
\hline Amoxicillin & $100 \% *$ & $100 \%$ & $100 \%$ & $0 *$ \\
\hline Amoxicillin/Clavulanic & $50 \%$ & -- & -- & 0 \\
\hline \multicolumn{5}{|l|}{ Acid } \\
\hline Ampicillin & $100 \%$ & $100 \%$ & $100 \%$ & 0 \\
\hline Aztreonam & $50 \%$ & $100 \%$ & $100 \%$ & $100 \%$ \\
\hline Cefepime & $100 \%$ & $100 \%$ & $100 \%$ & 0 \\
\hline Cefotaxime & $100 \%$ & $100 \%$ & $100 \%$ & 0 \\
\hline
\end{tabular}




\begin{tabular}{lcccc}
\hline Cefoxitin & $0 *$ & 0 & 0 & 0 \\
Ceftazidime & $100 \%$ & $100 \%$ & $100 \%$ & $100 \%$ \\
Ciprofloxacin & $50 \%$ & 0 & 0 & 0 \\
Ertapenem & 0 & 0 & 0 & 0 \\
Gentamycin & $50 \%$ & $100 \%$ & $100 \%$ & 0 \\
Imipenem & $0 \%$ & 0 & 0 & 0 \\
Levofloxacin & $50 \%$ & 0 & 0 & 0 \\
Meropenem & 0 & 0 & 0 & 0 \\
Sulfamethoxazole- & $50 \%$ & 0 & 0 & 0 \\
Trimethoprim & & & & 0
\end{tabular}

Trimethoprim

Goiás, 2019.

*Only valid values considered. **Absence of information regarding profile of ATB susceptibility.

The antimicrobial resistance profile of isolated non-fermenting gram-negative bacteria from blood culture exams of the NBs admitted to the IMCU and NICU, demonstrated that 03 patients presented resistance to the antibiotic, respectively being Aztreonam for $P$. aeruginosa, Ceftazidime and Gentamycin for Stenotrophomonas maltophilia.

Table 2. Antimicrobial resistance profile of Enterococcus sp. and Staphylococcus spp. Isolated from the NBs blood culture exams $(\mathrm{N}=45)$ admitted to the IMCU and NICU at an institution specialized in maternal-infant health.

\begin{tabular}{|c|c|c|c|c|c|c|c|c|}
\hline ANTIMICROBIAL & $\begin{array}{c}E . \\
\text { Faecalis } \\
(\mathrm{n}=01)\end{array}$ & $\begin{array}{c}S . \\
\text { Aureus } \\
(\mathrm{n}=04)\end{array}$ & $\begin{array}{c}S . \\
\text { auricularis } \\
(\mathrm{n}=01)\end{array}$ & $\begin{array}{c}S . \\
\text { Capitis } \\
(\mathrm{n}=06)\end{array}$ & $\begin{array}{c}S . \\
\text { cohnii } \\
(\mathrm{n}=01)\end{array}$ & $\begin{array}{c}S . \\
\text { epidermidis } \\
(\mathrm{n}=20)\end{array}$ & $\begin{array}{c}S . \\
\text { haemolyticus } \\
(\mathrm{n}=08)\end{array}$ & $\begin{array}{c}S . \\
\text { hominis } \\
(\mathrm{n}=02)\end{array}$ \\
\hline Ciprofloxacin & 0 & $0 *$ & -- & $100 \% *$ & $100 \%$ & $62.5 \% *$ & $87.5 \%$ & $100 \% *$ \\
\hline Clindamycin & -- & 0 & 0 & $33.3 \%$ & $100 \%$ & $30 \%$ & $37.5 \%$ & $100 \%$ \\
\hline Erythromycin & $100 \%$ & $50 \%$ & 0 & $50 \%$ & $100 \%$ & $63.1 \% *$ & $100 \%$ & $100 \%$ \\
\hline Gentamycin & -- & 0 & 0 & $100 \%$ & 0 & $75 \%$ & $75 \%$ & $100 \%$ \\
\hline Levofloxacin & -- & 0 & 0 & $100 \%$ & $100 \%$ & $50 \% *$ & $100 \% *$ & $50 \%$ \\
\hline Linezolid & 0 & 0 & 0 & 0 & 0 & 0 & 0 & 0 \\
\hline Oxacillin & -- & $25 \%$ & 0 & $100 \%$ & $100 \%$ & $85 \%$ & $100 \%$ & $100 \%$ \\
\hline Penicillin & 0 & $100 \%$ & $100 \%$ & $100 \%$ & $100 \%$ & $100 \%$ & $100 \%$ & $100 \%$ \\
\hline Rifampicin & $100 \%$ & 0 & 0 & $16.6 \%$ & 0 & $10 \%$ & $12.5 \%$ & 0 \\
\hline Tetracycline & $100 \%$ & $50 \%$ & 0 & 0 & 0 & $15.8 \% *$ & $12.5 \% *$ & 0 \\
\hline $\begin{array}{l}\text { Sulfamethoxazole/ } \\
\text { trimethoprim }\end{array}$ & -- & 0 & $100 \%$ & $16.6 \%$ & 0 & $65 \%$ & $37.5 \%$ & 0 \\
\hline Vancomycin & 0 & $0^{*}$ & 0 & 0 & 0 & 0 & $12.5 \%$ & 0 \\
\hline
\end{tabular}

Goiás, 2019.

*Only valid values considered. **Absence of information regarding profile of ATB susceptibility.

\section{DISCUSSION}

Among the aspects related to the infection of NB, the following were identified gestational age $<37$ weeks from $42(93.3 \%)$, low birth weight between $<750 \mathrm{~g}$ to $1.499 \mathrm{~g}$, in this study 33 were found $(73,3 \%)$ in this weight range. These findings corroborate the literature, which points to prematurity as one of the factors linked to the occurrence of infections in the neonatal period (COSTA et al., 2016; DE OLIVEIRA, 2016). Furthermore, $35(77.7 \%)$ NB were submitted to some type of CVC during admittance, of these, 22 (48.8\%) used PICC, 4 (8.8\%) UC and $9(20.0 \%)$ SLC. Studies performed by TIMSIT et al. (2011), pointed to these devices as risk factors for bloodstream infection (BSI). These selfsame authors gave further analysis to intravascular devices, capable of preventing infections related to catheters, such as use of curatives impregnated with antiseptic; however, reinforce the risk of contributing to the selection of resistant strains, thus prudence should be used in its application. On the other hand, these devices may prevent the formation of biofilms.

The incidence of mortality was $8(17.7 \%)$ occurrences, evaluated as worrying when compared to the rate of $11.9 \%$ published in the study by Brito et al. (2010). It is believed that these data reach higher rates, if we consider the problems faced in the data collection process, among those, failures in the correct completion of the HICC notification forms and in the records of NBs and mothers, 
together with underreporting. For this reason, one cannot state that the mortality rate is exclusively related to infection (DE OLIVEIRA et al., 2016; BRITO et al., 2010).

The use of empirical treatment on 776 NBs, although corroborating with the emergency strategy guidelines, for the start of treatment, did not exclude the need for diagnosis confirmation, since this procedure is a determining factor for the implementation of adequate therapy. In this way, this therapy should be used on average for a period of 72 hours, which is the time necessary for concluding microbiological analyses and the susceptibility profile of microorganisms isolated from ATB (AIZENSTEIN, 2016).

In terms of the profile for antimicrobial resistance, those isolated from NBs blood cultures were elevated. An example is enterobacteriaceae with $100 \%$ resistance to cefepime and ceftazidime, well above the data published by other studies, which was 20 to $44 \%$ (BRITO et al., 2010), which reveals a disconcerting reality concerning the microbiota circulating in the analyzed service.

Regarding the resistance profile of NFGNB, it was found that $P$. aeruginosa were $100 \%$ resistant to aztreonam and $100 \%$ of S. maltophilia resistant to ceftazidime and gentamycin. Already $1.1 \%$ of $\mathrm{S}$. aureus isolates were resistant to oxacillin. Investigation also confirmed that $12.5 \%$ ) of the isolates of $S$. haemolyticus were resistant to vancomycin. Studies performed as of 1994 with blood culture samples from NB suspected of sepsis identified that nearly all the gram-negatives were resistant to carbapenems and $62 \%$ of the isolates of Pseudomona ssp. were multidrug resistant.

However, the isolates of coagulase-negative staphylococci (CNS) in our study, 100\% of $S$. capitis were resistant to ciprofloxacin, gentamycin, levofloxacin, oxacillin and penicillin; $100 \%$ of $S$. haemolyticus were resistant to erythromycin, levofloxacin, oxacillin and penicillin and $100 \%$ of $S$. hominiseram were resistant to ciprofloxacin, clindamycin, erythromycin, gentamycin and oxacillin and penicillin. These findings confirm those of previous studies (BRITO et al., 2010).

Judging the significance of CNS is vital, since we are dealing with the most commonly isolated pathogen in the NICU. Therefore, CNS infection in these NBs is associated with high morbidity, including the impairment of neurological development. However, the diagnosis can be complex, bearing in mind the difficulty of obtaining these, which on many occasions is more than just a blood sample per culture (KUSAHARA et al., 2016; BERLAK et al., 2018).
Studies have reported that artificial hospital materials, such as intravascular devices, can be colonized by CNS, forming a biofilm that adheres to the device, which resists the defense system of the host and has a diminished susceptibility to the agents of ATB (BERLAK et al., 2018; REVDIWALA; RAJDEV; MULLA, 2012).

It is thus considered that these findings are suggestive of cross contamination, between the isolates of these surfaces and those identified in the blood culture results of the NBs analyzed in this study. As we are dealing with a cross-sectional study, there is the possibility of biases and limitations in the study, from the lack of medical records and files of the mothers and the NBs. Then one can add to this the therapeutic management of ATB in a predictable fashion, divergent to the guidelines.

\section{CONCLUSION}

The analysis showed that infection by NB multidrug-resistant organisms admitted to a neonatal intermediate care unit and intensive care unit occurred more frequently in NICU admissions $(62.3 \%)$, in males $(64.4 \%)$, whose predominant year of birth was 2011 (57.8\%), gestational age <37 weeks $(93.3 \%)$, birth weight from 1000 to $1499 \mathrm{~kg}$ $(35.5 \%)$, with normal birth $(53.3 \%)$. and death in $17.8 \%$. Regarding antimicrobial resistance, in enterobacteria it was $100 \%$ to cefepime and ceftazidime, in NF-GNB, it was found that P. aeruginosa were $100 \%$ resistant to aztreonam and $100 \%$ S. maltophilia with resistance to ceftazidime and gentamicin. For CNS, $100 \%$ of S. capitis were resistant to ciprofloxacin, gentamicin, levofloxacin, oxacillin and penicillin; $100 \%$ of S. haemolyticus were resistant to erythromycin, levofloxacin, oxacillin and penicillin, $12.5 \%$ of $\mathrm{S}$. haemolyticus isolates were also resistant to vancomycin. and $100 \%$ of S. hominis were resistant to ciprofloxacin, clindamycin, eritoromycin, gentamicin and oxacillin and penicillin. And identified the use of empirical antimicrobial treatment.

This analysis points to the importance of management indicators in signaling patient safety failures and antimicrobial therapy, concerning neonatal infection in a capital of Center-West of Brazil.

Therefore, these challenges faced on a daily basis by the multiprofessional team of a hospital of reference, should implement a process of change to the scenario, in addition to proposing the creation of a protocol propaedeutic with the multiprofessional team, with the HICC and its managers, which 
should then go on to be implemented and assessed regularly by the service.

Finally, further studies are needed to address the issue of newborn exposure to multidrugresistant organisms, admitted to the neonatal intermediate care unit and the intensive care unit, in order to ensure adequate protection against diseases. potentially arising from the occurrence of such infections.

This research has not received specific funding from any public, commercial or nonprofit funding agency.

RESUMO: Objetivou-se descrever a infecção por microorganismo multirresistente em recém-nascidos na unidade de cuidados intermediários neonatais e unidade de cuidados intensivos de referência. Tratou-se de estudo transversal de natureza epidemiológica, composto por 931 fichas e/ou prontuários de notificação da Comissão de Controle de Infecção Hospitalar (CCIH), no período junho a setembro de 2012 . Foram 870 recémnascidos $(\mathrm{RN})$, admitidos nas unidades de terapia intensiva neonatal e de cuidados intermediários, como amostra final 45 RN apresentaram infecção de corrente sanguínea por microorganismo multirresistente. Dessas análises destacam-se os resultados: idade gestacional < 37 semanas em 42 (93,3\%); baixo peso ao nascer entre $<750 \mathrm{~g}$ a $1.499 \mathrm{~g}$. O perfil de resistência à enterobactérias foi de $100 \%$ para o cefepime e ceftazidime, e para as bactérias gram-negativas não fermentadoras, verificou-se que (100\%) da P.aeruginosa era resistente ao aztreonam, (100\%) de S.maltophilia resistente à ceftazidima e à gentamicina; Entretanto, $(1,1 \%)$ dos isolados de $S$. aureus eram resistentes à oxacilina e $(12,5 \%)$ de $S$. haemolyticus conferiu resistência à vancomicina. Esses resultados são preocupantes e demonstram a relevância do monitoramento, propondo a elaboração de protocolo propedêutico em consenso com a equipe multiprofissional, com a CCIH e gestores a ser implementado e avaliado, regularmente pelo serviço.

PALAVRAS-CHAVE: Resistência Microbiana a Medicamentos. Resistência a Múltiplos Medicamentos. Segurança do Paciente. Serviços de Saúde da Criança. Recém-Nascido.

\section{REFERENCES}

AIZENSTEIN, M. L. Fundamentos para o uso racional de medicamentos. 3. ed. Rio de Janeiro: Guanabara Koogan, 2016. 360 p.

BARBOSA, F. S. Higienização das mãos: Monitoração da adesão dos profissionais de saúde numa instituição pública da rede estadual do Rio de Janeiro: um desafio à administração do serviço de controle de infecção hospitalar. Brazilian Journal of Health Review, Curitiba, v. 2, n. 2, p. 1323-1355, 2019.

https://doi.org/10.17058/reci.v4i1.4052

BELELA-ANACleto, A. S. C.; SOUSA, B. E. C.; YOSHIKAWA, J. M.; AVELAR, A. F. M.; PEDREIRA, M. DA L. G. Higienização das mãos e a segurança do paciente: perspectiva de docentes e universitários. Texto Contexto Enfermagem, v. 22, n. 4, p. 901-8, 2013. https://doi.org/10.1590/s0104-07072013000400005

BERLAK, N.; SHANY, E.; BEN-SHIMOL, S.; CHERTOK, I. A.; GOLDINGER, G.; GREENBERG, D.; MELAMED, R. Late onset sepsis: comparison between coagulase-negative staphylococci and other bacteria in the neonatal intensive care unit. Infectious Diseases, Londres, v. 50, n. 10, p. 764-770, 2018.

https://doi.org/10.1080/23744235.2018.1487075

BRITO, D. V. D.; BRITO, C. S.; RESENDE, D. S.; MOREIRA DO, O. J.; ABDALLAH, V. O. S.; GONTIJO FILHO, P. P. Nosocomial infections in a Brazilian neonatal intensive care unit: a 4-year surveillance study.

Revista da Sociedade Brasileira de Medicina Tropical, Uberaba, v. 43, n. 6, p. 633-637, 2010. https://doi.org/10.1590/s0037-86822010000600006

CARVALHO, M. S. M.; ANDRADE, D. F. R.; SOUSA, A. F. L.; VALLE, A. R. M. C.; FREITAS, D. R. J.; NASCIMENTO, G. C.; ANDRADE, D.; WATANABE, E. Nasal colonization with Staphylococcus aureus in nursing students: ground for monitoring. Revista brasileira de enfermagem, Brasília, v. 69, n. 6, p. 10461051, 2016. https://doi.org/10.1590/0034-7167-2016-0210 
CAVALCANTE, A. P.; PADOVEZE, M. C. Boletim Informativo sobre a Segurança do Paciente e Qualidade em Serviços de Saúde. Brasília: Agência Nacional de Vigilância Sanitária, 2012.

COSTA, P.; DÓREA PAIVA, E.; FUMIKO KIMURA, A.; ELCI DE CASTRO, T. Fatores de risco para infecção de corrente sanguínea associada ao cateter central de inserção periférica em neonatos Acta paul. enferm, São Paulo, v. 29, n. 2, p. 161-168, 2016. https://doi.org/10.1590/1982-0194201600023

DATASUS - Departamento de Informática do SUS. [Internet]. Informações de Saúde (TABNET).

Disponível em: $<$ http://www2.datasus.gov.br/DATASUS/index.php?area=02 >. Acesso em [26 maio 2019].

DE OLIVEIRA, C. O. P.; SOUZA, J. R. S.; MACHADO, R. C.; FEIJÃO, A. R.; DE SOUZA, N. L. Fatores de risco para sepse neonatal em unidade de terapia: Estudo de evidência. Cogitare Enfermagem, Curitiba, v. 21, n. 2, p. $01-09,2016$. https://doi.org/10.5380/ce.v21i2.42845

DE SÁ, N. E. R.; VERDE, R. M. C. L.; DO NASCIMENTO, M. H.; SOARES, L. F.; DE OLIVEIRA, E. H. Perfil hematológico de recém-nascidos de uma Unidade de Terapia Intensiva neonatal de Teresina-PI. Revista Eletrônica Acervo Saúde, Piracicaba, v. 11, n. 1, p. e112, 2019. https://doi.org/10.25248/reas.e112.2019

ESCOSTEGUY, C. C.; PEREIRA, A. G. L.; MEDRONHO, R. A. Três décadas de epidemiologia hospitalar e o desafio da integração da Vigilância em Saúde: reflexões a partir de um caso. Ciência \& Saúde Coletiva, Rio de Janeiro, v. 22, p.3365-3379, 2017. https://doi.org/10.1590/1413-812320172210.17562017

GARLAND, J. S.; KANNEBERG, S.; MAYR, K. A.; PORTER, D. M.; VANDEN HEUVEL, A.; KURZIAK, J, MCAULIFFE, T. L. Risk of morbidity following catheter removal among neonates with catheter associated bloodstream infection. Journal of neonatal-perinatal medicine, Cleveland, v. 10, n. 3, p. 291-299, 2017. https://doi.org/10.3233/npm-16137

HAWKEY, P. M. Multidrug-resistant Gram-negative bacteria: a product of globalization. Journal of Hospital Infection, Londres, v. 89, n. 4, p. 241-247, 2015. https://doi.org/10.1016/j.jhin.2015.01.008

KUSAHARA, D. M.; AVELAR, A. F. M.; BRAGA, A. V.; DE MELO MENDES, M. T.; PETERLINI, M. A. S.; PEDREIRA, M. L. G. Contamination of alcohol preparations for hand hygiene in a pediatric intensive care unit. Enfermagem Uerj, Rio de Janeiro, v. 24, n. 2, p. 1-8, 2016. https://doi.org/10.12957/reuerj.2016.10640

MEDEIROS, E. A.; GRINBERG, G.; ROSENTHAL, V. D.; BICUDO ANGELIERI, D.; BUCHNER FERREIRA, I.; BAUER CECHINEL, R.; ZANANDREA, B. B.; ROHNKOHL, C.; REGALIN, M.; SPESSATTO, J. L.; SCOPEL PASINI, R.; FERLA, S. Impact of the International Nosocomial Infection Control Consortium (INICC) multidimensional hand hygiene approach in 3 cities in Brazil. American journal of infection control, Columbia, v. 43, n. 1, p. 10-15, 2015. https://doi.org/10.1016/j.ajic.2014.10.001

PAULA, C. R.; PELAZZA, B. B.; MAIA, L. G.; BARROS, P. S.; ANDRADE, M. M.; PARANAÍBA, J. F. F. S.; MENDONCA, G. S. PALOS, M. A. P. Microbiological profile of the nasal cavity of professionals from the emergency sector and mobile urgency care service localized in a southwest municipality of Goiás. Bioscience Journal, Uberlândia, v. 34, n. 5, p. 1432-1442, 2018. https://doi.org/10.14393/bj-v34n5a2018-40131

REVDIWALA, S.; RAJDEV, B. M.; MULLA, S. Characterization of bacterial etiologic agents of biofilm formation in medical devices in critical care setup. Crit Care Res Pract, Califórnia, v. 2012, p. 945805, 2012. https://doi.org/10.1155/2012/945805

SILVA, L. C. S.; CARRIJO, F. M. M.; PALOS, M. A. P.; BARRETO, R. A. S.; SUZUKI, K. Conhecimento e percepção dos trabalhadores de saúde sobre colonização por microrganismos multirresistentes. Saúde e ciência em ação, Goiânia, v. 2, n. 2, p. 31-43, 2016. https://doi.org/10.4025/cienccuidsaude.v11i2.11181 
TIMSIT, J. F.; DUBOIS, Y.; MINET, C.; BONADONA, A.; LUGOSI, M.; ARA-SOMOHANO, C.; HAMIDFAR-ROY, R.; SCHWEBEL, C. New materials and devices for preventing catheter-related infections. Annals of Intensive Care, v. 1, p. 34, 2011. https://doi.org/10.1186/2110-5820-1-34

TOMAS, M. E.; KUNDRAPU, S.; THOTA, P.; SUNKESULA, V. C.; CADNUM, J. L.; MANA, T. S. C.; JENCSON, A.; O'DONNELL, M.; ZABARSKY, T. F.; HECKER, M. T.; RAY, A. J.; WILSON, B. M.; DONSKEY, C. J. Contamination of health care personnel during removal of personal protective equipment. JAMA internal medicine, Chicago, v. 175, n. 12, p. 1904-1910, 2015.

https://doi.org/10.1001/jamainternmed.2015.4535 